\title{
The Mommy Trek? Working Women's Choices
}

Susan P. Eisner, (E-mail: seisner@ramapo.edu), Ramapo College of New Jersey

\begin{abstract}
A quarter century after Felice Schwartz urged companies to craft policies accommodating parental responsibilities or risk losing talented women, many highly educated women are leaving traditional careers. Is the $21^{\text {st }}$ century workplace experiencing a "Mommy Trek" foreshadowed by Schwartz's recommendation for a Mommy Track? What choices are today's working women making? Do things turn out as planned? Will Family Friendly programs keep women from leaving? This paper presents results of a study conducted to explore the Mommy Trek.
\end{abstract}

\section{INTRODUCTION}

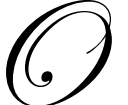

n January 1, 1989, Felice N. Schwartz's Harvard Business Review article "Management Women and the New Facts of Life" triggered a national dialog in business circles. Schwartz identified two categories of working women: those whose primary commitment was work, and those with dual commitment to work and family. She spotlighted the business costs of losing those with dual commitment, and recommended creation of company policies to support workers on that Mommy Track. Twenty-six years later, Sylvia Hewlett and Carolyn Luce's Harvard Business Review article "Off-Ramps and On-Ramps" pinpointed a turn-of-this-century trend and its costs to women: many highly educated women appear to be leaving traditional careers. These women average 2.2 years off (1.2-1.5 years in business and banking/finance), and their earnings tend to drop 18\% for that time away (28\% in business and banking/finance). The earnings loss averages $37 \%$ when women stay out three years or more. Some $37 \%$ of women with graduate degrees or college degrees with honors "off-ramp" at some point; $93 \%$ want to return to work in the future. But many of these women find it hard to gain reentry to the workplace they left. Eventually, some three out of four are able to return to work. Only $40 \%$ of off-rampers return to full-time jobs (2005).

At the same time, demographic shifts are projecting tighter U.S. labor markets (Looming Labor Shortages, 2001; Gandossy and Kao, 2004). The implication for business is striking. Women are now earning the majority of college, masters, and professional degrees, and women are earning the same number of doctoral degrees as men (Catalyst Quick Takes, 2005). By 2002, women aged 25-29 held more bachelors, masters, professional, doctoral degrees or higher than same-aged men held college degrees (Catalyst Quick Takes, 2005). Researchers are beginning to predict a "brain drain" as many educated, talented women "opt out" of traditional full-time employment (McCracken, 2000; Belkin, 2003; Wallis, 2004; Shiller, 2005).

\section{CHARTING A PATH}

As people become more educated and enter the workplace, they are increasingly faced with deciding how to best achieve both personal and career goals (The Next Generation, 2005; Story, 2005; Werner et. al., 2005; Dalke, 2006). Academics and practitioners have begun to explore and prescribe for the resulting juxtaposition: valuable female employees deciding whether to stay or leave the workplace just as demand for their talent is likely to increase. Schwartz published a second landmark article in Harvard Business Review, "Women as a Business Imperative." It directly affronted employers for failure to craft policies reflecting the demographic reality that $85 \%$ of women have children, and pointed out the financial benefits companies who adopt family friendly policies would accrue (1992). Eight years later, Deloitte's CEO/Chairman published guidelines for how companies might adapt strategies his company had used successfully to increase female worker retention (McCracken, 2000). 
Around that same time, Basic Books reissued The Way We Never Were: American Families and the Nostalgia Trap documenting that the idyllic view of traditional family of the 1950s has been romanticized, and that children can be raised properly in many ways (Coontz, 2000). Owl Books reissued The Time Bind: When Work Becomes Home and Home Becomes Work, which explored why workers were not accessing available family friendly policies, and found that many chose to be at work because they found it less stressful than being home (Hochschild, 2001). W.W. Norton \& Co. reissued The Feminine Mystique, which chronicled a "nameless, aching dissatisfaction" among stay-at-home post-World War II women (Friedan with Quindlen, 2001). Penguin Books joined this cycle of reissuing groundbreaking studies with its update of The Second Shift, which found that couples have insufficient time, working women continue to do most housework and accept the extra responsibility to maintain harmony, and the health and marital relations of many of these women suffer as a result (Hoschschild and Machung, 2003).

New reports continue to join the foundational literature. In addition to the 2005 Harvard Business Review study by Hewlett and Luce referred to above, two other frequently cited reports were released that year. Wharton's "Returning to Business After a Hiatus" found that women are "stepping out" from corporate life not just for their families but also due to inflexible practices, inability to make a difference, and inadequate opportunities for professional development at work (Mcgrath et.al., 2005). The Families and Work Institute's "Overwork in America: When the Way We Work Becomes Too Much" found that only $29 \%$ of U.S. workers report being rarely or never overworked, and a correlation especially in college-educated workers between feeling overwhelmed by work and reduced interest to seek advancement. Further, that study found that having more than one child or children under 18 years old is not linked to feeling overworked, that being equally oriented toward work and family (dual-centric) or toward family above work (family-centric) is more positively linked with health and work success than is being oriented toward work above family (work-centric), and that those responsible for elder care tend to feel the most overworked (Galinsky et.al., 2005).

The timing of that body of research appears to be in sync with public dialog. Widely distributed mainstream media have explored related topics. The New York Times Magazine, for instance, published "The Opt Out Revolution" which profiled eight women who graduated from Princeton, and concluded that working women encounter "maternal wall blocks" long before the glass ceiling and are rejecting the workplace not wanting to do what it has defined success to entail (Belkin, 2003). Time published "The Case for Staying Home," which reported that most accomplished women leaving traditional employment for parenting having decided "you can have it all, just not all at the same time." Most of these women intend to return to work - they see themselves as stopping out not dropping out (Wallis, 2004). Moreover, a recent New York Times article spotlighted a contemporary counterpart to the Mommy Track Schwartz introduced decades earlier. It described a Daughter Track to be drawing from the workplace middleage women who are caring for ailing parents. Seventy-one percent of those providing 40-plus hours of elder care per week are women; $88 \%$ of those women take a leave of absence, quit, or retire (Gross, 2005). Moreover, a recent ABC News segment on Good Morning America entitled "Mommy Wars: To Work or Stay at Home" drew such attention that 3,749 responses were posted on its public message board within days of telecast (GMA Message Board, 2006).

Against this backdrop, formative questions emerge. Is the contemporary United States workplace experiencing a "Mommy Trek" foreshadowed by Schwartz's recommendation for a Mommy Track a quarter-century earlier? What choices are women charting this path making? What is the nature of their journey? Will Family Friendly programs keep women like them from leaving work?

\section{PURPOSE AND METHOD}

This paper is stimulated by a stream of published research regarding gender and work, a long-established field. A review of the literature finds a marked shift in the focus of its researchers. Prior interest to explore the Glass Ceiling has produced prolific findings that appear to have for the most part both validated and described the concept of workplace barriers to advancement that confront women (Federal Glass Ceiling Commission, 1995). As tracked above, today's research regarding gender and work increasingly appears to be exploring what is frequently referred to as the Family Friendly work place - the policies and practices ranging from flextime to telecommuting to job-sharing to onsite childcare that organizations can adopt to accommodate worker desire for work-life balance. But what if the factors resulting in women leaving the workplace are different from conditions that such programs will address? 
Contributing to the literature by helping to investigate whether the exiting female is indeed a Mommy Trek would appear to be both relevant and timely.

In reviewing the existing literature, some 100 articles were located on-line through academic databases including ProQuest and LexisNexis using working women, stay-at-home mothers, stay-at-home dads, women leaving work, dual-income families, mommy track, daddy track, work-life balance, children of working parents, family friendly, and Generation Y and work among the search locators. Practitioner websites were also sampled using those search locators. Foundational reports, some published in books recently reissued, were accessed as well.

From that research, it became clear that the implications of working women's evolving work-life patterns are complex, and should be investigated within the environmental context in which those patterns are emerging. That is, the work-life choices women make straddle the professional and personal arena of their lives, are impacted by these arenas, and impact them in turn. As a result, to determine whether Family Friendly employment policies will alter the reported tendency of women to leave traditional employment, it is important to understand the choices that working women are making, and what happens to them as a result of those choices. Having made their choices, would they make the same choices again? Do commonalities emerge in their hindsight reflections?

The academic and practitioner literature contain some voices of high-achieving women discussing work-life choices they have made. The Internet provides multiple forums where women can and do describe their experiences and offer their opinions. But it is unclear how representative, and of what factors, these views are. On the other hand, the Families and Work Institute's Ask the Children study went a long way in providing a fuller picture; it investigated the perspectives of both parents and children regarding work-life choices made by adults. The study found that children are not less happy or healthy when both parents work, but are negatively impacted by spillover parental stress and changing schedules. It reported that children learn more about the work world from their mothers than from their fathers, and that children's top wish to improve the impact on their lives of their parent's work was not that they have more time together - but that their parents would be less stressed and tired (Galinsky, 1999).

Based on findings in foundational and contemporary literature, an original study was conducted for this paper. In-depth questions explored the Mommy Trek and its consequences from the qualitative perspective of adult women who have made their formative work-life choices. Analytical context is provided through existing literature. This paper may well be the first academic study to provide a $21^{\text {st }}$ century platform for the insights of adult women regarding work-life choices and the resulting impact.

\section{CHOICES MADE: INTERVIEW RESULTS}

To gather the views of adult women, a set of ten questions was created using the reviewed literature to identify relevant areas to probe. The questions were administered as a pilot study to twelve women selected for the diversity of relevant factors they collectively contain. The questioner knew the respondents, but knew none of the respondents well enough for their answers to be predetermined. The questions were presented as a virtual interview: they were distributed by e-mail and open-ended in nature, and solicited comments not prompted by the questions. This method was chosen to allow respondents the time and privacy to construct answers to questions they might find complex or sensitive to answer.

Respondents were offered the option of being interviewed in person if they would prefer that, and were instructed to ask if they needed clarification regarding any of the questions. Fourteen potential participants were approached. Twelve readily agreed to participate. The other two agreed to participate but apologized for being unable to find the time before the deadline. Each of the twelve respondents chose to submit their responses in writing. Those responses are reported below in cohort groups corresponding to the shared presence of children in the respondents' lives. Together participants represent the range of factors itemized in Figure 1. 
Figure 1: Factors Represented By The 12 Respondents

\begin{tabular}{|l|l|}
\hline Gender & Female \\
\hline National origin & 11 USA, 1 Russia \\
\hline Age & $30-60+$ \\
\hline Children & None, new baby, children at home, grown children, ill child \\
\hline Location & US: urban, suburban, exurban; north, east, south, west \\
\hline Marital status & Married, remarried, divorced and single, never married \\
\hline Employment status & Not working, volunteering, seeking reemployment, working part-time, working full-time \\
\hline Fields & $\begin{array}{l}\text { Profit, non-profit; financial services, counseling, television, management consulting, healthcare, } \\
\text { arts/media, academia }\end{array}$ \\
\hline Work-life choices made & Leave full-time employment, remain employed full-time, be self-employed, relocate, volunteer \\
\hline $\begin{array}{l}\text { College/university } \\
\text { degree awarded }\end{array}$ & $\begin{array}{l}\text { Brown, Colgate, Duke, Farleigh Dickinson, Florida State, Fordham, Harvard, Hunter, Iona, New } \\
\text { Jersey Institute of Technology, New York, Nova Southeastern, Pace, Ramapo, } \\
\text { Pennsylvania/Wharton, Scranton, Yale }\end{array}$ \\
\hline
\end{tabular}

\section{Cohort Set 1: Respondents With Young Children At Home}

These women each have young children at home, and are the youngest of the 12 respondents. All are married. Although only one of these women, Respondent 2 (R2), reports having had a long-term goal and plan in place when making her formative work-life choices, all would make the same work-life choices again, mentioned having made those choices with their husbands, described finding motherhood more difficult than anticipated, and made changes in their work lives as a result of motherhood.

But that is where their similarities appear to end. The youngest, R3, possesses the fewest advanced degrees. While a full-time mother, she became a regular volunteer in a new field in which she is now pursuing a second college degree to enter full-time. She would prefer to return to the corporate career she left, but feels its demands are incompatible with her family's interests. She expresses frustration that, while some corporations are offering flexible arrangements to retain workers who become pregnant, they do not provide adequate reentry routes for qualified mothers who have stayed home to raise children.

On the other hand, R1 had outgrown her current work at the time she became a parent. Newly married and wanting to be open to relocate to accommodate her husband's work, she describes having been stressed by the thought of someone spending more time with her child than she does. She has taken her maternity leave as a chance to pursue a long-held dream of self-employment and civic involvement.

The oldest, R2, is in her second marriage and has a late-in-life child. She has chosen to delay pursuit of promotion through a compressed work schedule allowing her to be at home during her child's preschool years. But the supervisor with whom she arranged this has left the organization. New administrators and changed workplace goals altered expectations of all employees in ways requiring more productivity, collaboration, and on-site work.

Each of these women with young children at home encountered a different unforeseen hurdle. R3 had a child with a medical condition needing ongoing parental care, and found inability to reconcile corporate and family life. R1 experienced an unexpected feeling of being overwhelmed by change and responsibility, and wanting to be the one to spend most time with her child. R2 found a change in work conditions that presented unforeseen pressures. Using different words, though, each expressed deep satisfaction from, commitment to, and appreciation for motherhood as they begin it. 
Figure 2: Cohort Set 1

\begin{tabular}{|c|c|c|c|}
\hline $\begin{array}{c}\text { Cohort Set } \\
1\end{array}$ & Respondent 1 & Respondent 2 & Respondent 3 \\
\hline Age & 35 & $40-44$ & 30 \\
\hline $\begin{array}{l}\text { Children at } \\
\text { home }\end{array}$ & New baby & Toddler & 2 in early elementary \\
\hline $\begin{array}{l}\text { Marital } \\
\text { status }\end{array}$ & Married & $2^{\text {nd }}$ marriage & Married \\
\hline $\begin{array}{l}\text { Employment } \\
\text { status }\end{array}$ & $\begin{array}{l}\text { On leave from full-time middle } \\
\text { school job; resume private practice at } \\
\text { reduced hours (6-8 hours per week) }\end{array}$ & $\begin{array}{l}\text { Tenured college professor; } \\
\text { compressed work schedule }\end{array}$ & $\begin{array}{l}7^{\text {th }} \text { year as at-home mother; regular } \\
\text { elementary volunteer; earning } 2^{\text {nd }} \\
\text { college degree in teaching }\end{array}$ \\
\hline $\begin{array}{l}\text { Academic } \\
\text { degrees }\end{array}$ & $\begin{array}{l}\text { Doctor of Psychology/Child and } \\
\text { School; BA Psychology }\end{array}$ & $\begin{array}{l}\text { Doctor of Business } \\
\text { Administration/ } \\
\text { Accounting; MBA Finance; } \\
\text { BS Accounting }\end{array}$ & $\begin{array}{l}\text { BS Business Administration/ } \\
\text { Management and Information Systems }\end{array}$ \\
\hline $\begin{array}{l}\text { Choice } \\
\text { made }\end{array}$ & $\begin{array}{l}\text { Leave full-time public sector work to } \\
\text { be home with baby; seek self- } \\
\text { employment while on leave; } \\
\text { work/volunteer on non-profit board } \\
\text { part-time; add hours as child grows }\end{array}$ & $\begin{array}{l}\text { Delay pursuit of academic } \\
\text { promotion by reducing on site } \\
\text { time and non- essential work } \\
\text { to be home with child in pre- } \\
\text { school years }\end{array}$ & $\begin{array}{l}\text { Leave full-time corporate work to be } \\
\text { home with children in pre-school } \\
\text { years; volunteer part-time in education } \\
\text { until return to full-time work; } \\
\text { prioritize child's medical condition }\end{array}$ \\
\hline $\begin{array}{l}\text { Long-term } \\
\text { goal/plan }\end{array}$ & No & Yes & No \\
\hline $\begin{array}{l}\text { Would make } \\
\text { same choice }\end{array}$ & $\begin{array}{l}\text { Yes: It provided chance to branch } \\
\text { out; had outgrown current work; } \\
\text { made choice with husband to give up } \\
\text { one salary }\end{array}$ & $\begin{array}{l}\text { Yes: Children are a gift, and } \\
\text { young children need their } \\
\text { parents; chose with husband } \\
\text { to keep overhead low }\end{array}$ & $\begin{array}{l}\text { Yes: More satisfaction from mothering } \\
\text { than from work; made choice with } \\
\text { husband; his income made it possible }\end{array}$ \\
\hline But found & $\begin{array}{l}\text { Was initially scared and } \\
\text { overwhelmed; growing security in } \\
\text { parenting improved performance in } \\
\text { private practice }\end{array}$ & $\begin{array}{l}\text { Changed work conditions } \\
\text { presented unforeseen } \\
\text { pressures; working from home } \\
\text { while caring for a child is } \\
\text { hard }\end{array}$ & $\begin{array}{l}\text { Choices are complex: Was successful, } \\
\text { dedicated, and driven but no part-time } \\
\text { at-home work offer; to mother is } \\
\text { harder than imagined; corporate } \\
\text { demands are incompatible with family }\end{array}$ \\
\hline
\end{tabular}

\section{Cohort Set 2: Respondents With Older Child At Home}

These women each have older children at home, and are a bit older than the prior cohort group. All are married, all possess graduate degrees, all left full-time corporate work as a first-time mother, and all mentioned their husbands supported their formative work-life choice. R6 is the only one of these three women to not have had a longterm goal and plan in place when making her formative work-life choices, and she is the only one of the group to report that she would not repeat the work-life choice she made.

Not only have these women come to different places, but they appear to have traveled different routes. R4 enjoyed the pace and drive of corporate life, but found she was entrepreneurial by nature. That combined with her corporate grounding appear to have prepared her for the long hours and multitasking involved in maintaining a private practice, which she coupled with academic employment as her children grew. She reports having resumed more traditional employment in part to serve as a role model for her younger child, a daughter.

R5 kept her corporate skills and experience sharp through freelance consulting as she raised her children. Combined with the educational credentials she possesses that are strongly valued in business, she feels ready to return to full-time employment. Like many of the women described in studies by Hewlett (2005) and McGrath (2005), though, she has not found a route to appropriate corporate reemployment. She expects to shift to the public sector, and is transitioning through part-time administrative work in higher education. On the other hand, R6 was unsatisfied with 
the job she left when her first child was born, and relocated with her family soon thereafter when her husband's job moved. She has served as a regular volunteer and earned a graduate degree while raising their three children. She reports having lost a sense of identify, value, and direction, and describes a lack of balance without work as a regular part of her life. In hindsight, she would have asked her husband to be more involved in parenting so she have could engaged in part-time work while mothering.

Only one of these women, R4, did not mention a single hurdle or unforeseen surprise. She had an entrepreneurial mother who ran a day-care center in their home, and has a close-knit extended family. She speaks of having entered motherhood both familiar with what it would be like, and what combining it with at-home work would entail. The other two women in this group expressed unforeseen hurdles, but they were different. R5 is finding that she cannot re-enter the corporate sector at an appropriate level, despite having strong credentials. R6 reports that years without work have depleted her confidence as a working person, and left her unsure of what place there might be for her in the workplace she has been out of for so long.

Figure 3: Cohort Set 2

\begin{tabular}{|c|c|c|c|}
\hline Cohort Set 2 & Respondent 4 & Respondent 5 & Respondent 6 \\
\hline Age & $45-49$ & $45-49$ & $45-49$ \\
\hline $\begin{array}{l}\text { Children at } \\
\text { home }\end{array}$ & $\begin{array}{l}1 \text { pre-teen; } 1 \text { grown in graduate } \\
\text { school }\end{array}$ & $\begin{array}{l}1 \text { teen at home; } 1 \text { teen awaiting } \\
\text { college; } 1 \text { in college }\end{array}$ & $\begin{array}{l}1 \text { pre-teen; } 1 \text { teen in middle } \\
\text { school; } 1 \text { teen awaiting college }\end{array}$ \\
\hline Marital status & Married & Married & Married \\
\hline $\begin{array}{l}\text { Employment } \\
\text { status }\end{array}$ & $\begin{array}{l}\text { Full-time tenured college } \\
\text { professor, regular adjunct, and } \\
\text { private practitioner }\end{array}$ & $\begin{array}{l}\text { Part-time higher education } \\
\text { administration; considering full-time } \\
\text { public sector work }\end{array}$ & $\begin{array}{l}\text { Regular volunteer in education; } \\
\text { considering return to work }\end{array}$ \\
\hline $\begin{array}{l}\text { Academic } \\
\text { degrees }\end{array}$ & $\begin{array}{l}\text { CPA; MBA Taxation; BS } \\
\text { Accounting }\end{array}$ & MBA Finance, BS and Engineering & $\begin{array}{l}\text { Masters Public Health; BS } \\
\text { Nursing }\end{array}$ \\
\hline Choice made & $\begin{array}{l}\text { Leave full-time corporate work to } \\
\text { be home with children, and start } \\
\text { private practice }\end{array}$ & $\begin{array}{l}\text { Leave full-time corporate work to be } \\
\text { home with children; work part-time } \\
\text { as freelance consultant }\end{array}$ & $\begin{array}{l}\text { Leave unsatisfying full-time } \\
\text { service job for flexible at-home } \\
\text { work to be with first child; after a } \\
\text { year, relocated with husband's } \\
\text { job; got graduate degree }\end{array}$ \\
\hline $\begin{array}{l}\text { Long-term } \\
\text { goal/plan }\end{array}$ & Yes & Yes & No \\
\hline $\begin{array}{l}\text { Would make } \\
\text { same choice }\end{array}$ & $\begin{array}{l}\text { Yes: Could not be effective } \\
\text { employee and first-time mother; } \\
\text { desire to succeed grew in self } \\
\text { employ; entrepreneurial; client } \\
\text { relations replaced corporate } \\
\text { competition; extended family; } \\
\text { husband supported any choice }\end{array}$ & $\begin{array}{l}\text { Yes: Have raised children to be } \\
\text { proud of; shaped their development } \\
\text { and growth; husband had stable } \\
\text { work and supported choice }\end{array}$ & $\begin{array}{l}\text { No: Had no idea how consuming } \\
\text { it would be; lost identify and self- } \\
\text { worth; lacked balance without } \\
\text { work; decided with husband, as } \\
\text { lacked child care funds at first }\end{array}$ \\
\hline But found & $\begin{array}{l}\text { Loved fast-paced corporate } \\
\text { environment/work; private } \\
\text { practice involved equally long } \\
\text { hours }\end{array}$ & $\begin{array}{l}\text { Built competencies and experience, } \\
\text { but they do not equate to career } \\
\text { would have if had stayed } \\
\text { traditionally employed; can not } \\
\text { reenter corporate sector at } \\
\text { appropriate level }\end{array}$ & $\begin{array}{l}\text { Better choice would have been to } \\
\text { maintain part-time work and to } \\
\text { have asked husband to take larger } \\
\text { share in parenting }\end{array}$ \\
\hline
\end{tabular}




\section{Cohort Set 3: Respondents With All Grown Children}

These three women all have grown children, and are older than the prior cohort groups. There the similarities end. Two of the three had no long-term goal or plan at the time their formative work-life choices were made, but a third had something of a long-term view. She, R8, holds the senior most position of any of the ten women interviewed who had children, and is the only one of the ten to have remained employed full-time throughout her married life. She chose to retain full-time corporate employment because she enjoyed the work, found it meaningful, and benefited others.

R8 made her parental choices two decades ago, before changing policies and technology provided some of today's options. But she found her way. She asked her employer to give her a flexible schedule for the first four months after childbirth, was granted an exception allowing her to have that, and altered her work habits upon returning to full-time work months later. Her workdays have always been long but she has ever since started them in the early morning to be able to spend evenings with family at home, and avoids taking work home or traveling.

R8's entrepreneurial husband worked from home, and was the primary daytime caregiver when their child was young. Though she turned down several job offers over the years because they would have meant relocating her family or traveling extensively, she was able to provide financial security and stable benefits as her husband pursued entrepreneurial ventures. She is the only one among the three women in this cohort group to say she would make the same key choice again.

R7 reports she would again choose to be home as her children grew. During those at-home years, she supplemented parenthood with civic activity. But her marriage ended in divorce, and one of her five children had serious medical needs requiring constant care. She had not planned on having to raise her family on her own. Supporting her children as a single parent meant returning to full-time public sector work at a level and pay that were less than she had earned in corporate work, so that she could now receive essential benefits and not have to travel. In return, she has created the close lifetime bond with her children that prompted her initial choice to leave full-time corporate work. Since returning to full-time work, she has earned a graduate degree that allowed her promotion to management. She reports having done so, in part, to model the value of advanced education for her children.

Of the three women in this group, R9 is the most regretful about the work-life choices she has made. She left a prominent career as an on-air TV personality to relocate for her husband's career and join him in glamorous travel, has never been able to replicate the career satisfaction she enjoyed, and reports having lost her ambition and her way. Like R7, R9's (first) marriage ended in divorce. R9 describes two other unplanned exigencies as well: the romance and novelty of the life she had abandoned work for wore off, and were replaced by a loneliness and lack of stimulation. Moreover, she was diagnosed with breast cancer soon after remarrying, relocating a second time to join a new husband, and returning to freelance work. But the strength of R9's pull toward her children was seen twice: first in her unexpected decision to fire her child help and be the sole caregiver for her first baby, and then in her choice to return home to be with her two children full-time after her cancer diagnosis.

Each of these women would, in hindsight, have made some different choices. R9, who gave up a promising career to relocate with marriage, reports she should not have moved until she had established a good working situation for herself in the new location. R7, who had to raise five children alone, reports she would have worked part-time after leaving full-time employment had she known divorce would come. The high ranking corporate woman, R8, reports she might have reduced her work hours during her child's early years, and has more recently decided to telecommute one day per week in summer. Though R8 is the only woman in this group to say she would make the same key choice again, she is the only woman of the twelve sampled to use the word guilt. She describes every woman she speaks with as talking about remorse, and female senior managers as constantly second guessing the choices they have made and being increasingly concerned about providing elder care. 
Figure 5: Cohort Set 3

\begin{tabular}{|c|c|c|c|}
\hline Cohort Set 3 & Respondent 7 & Respondent 8 & Respondent 9 \\
\hline Age & $55-59$ & 50 & $55-59$ \\
\hline $\begin{array}{l}\text { Children at } \\
\text { home }\end{array}$ & 1 of 5 grown live at home & 1 grown & 2 grown \\
\hline Marital status & Divorced $10+$ years & Married & $2^{\text {nd }}$ marriage \\
\hline $\begin{array}{l}\text { Employment } \\
\text { status }\end{array}$ & $\begin{array}{l}\text { Full-time management job } \\
\text { in higher education }\end{array}$ & $\begin{array}{l}\text { Full-time senior manager in } \\
\text { corporate/service sector }\end{array}$ & Freelance writer and artist \\
\hline $\begin{array}{l}\text { Academic } \\
\text { degrees }\end{array}$ & $\begin{array}{l}\text { Masters Management/ } \\
\text { Accounting Controls; BS } \\
\text { Accounting }\end{array}$ & $\begin{array}{l}\text { BS Business Administration and } \\
\text { American Studies }\end{array}$ & BA History \\
\hline Choice made & $\begin{array}{l}\text { Leave full-time corporate } \\
\text { work to be home with } \\
\text { children; reject employer } \\
\text { offer for onsite childcare; } \\
\text { serve on civic clubs; } 10 \\
\text { years later, took part-time } \\
\text { work; } 2 \text { years later, took } \\
\text { full-time public sector job at } \\
\text { reduced pay, and earned } \\
\text { graduate degree }\end{array}$ & $\begin{array}{l}\text { Retain full-time corporate job with } \\
\text { meaning, value, and benefits; start } \\
\text { long day at major company at } 5 \mathrm{am} \\
\text { to leave at } 6 \mathrm{pm} \text { to be home with } \\
\text { family; avoid night/weekend travel } \\
\text { and work; now telecommute one } \\
\text { day weekly in summer; "Mr. Mom" } \\
\text { husband ran own business from } \\
\text { home }\end{array}$ & $\begin{array}{l}\text { Leave prominent TV career to move } \\
\text { cross country for husband; short-term } \\
\text { or freelance work through divorce, } \\
\text { remarriage and relocation; stopped } \\
\text { working a year after breast cancer } \\
\text { diagnosis to be full-time with children; } \\
2 \text { years later, returned to part-time } \\
\text { freelance work }\end{array}$ \\
\hline $\begin{array}{l}\text { Long-term } \\
\text { goal/plan }\end{array}$ & No & Yes and no & No \\
\hline $\begin{array}{l}\text { Would make } \\
\text { same choice }\end{array}$ & $\begin{array}{l}\text { Yes and no: Knew career } \\
\text { would be hurt but young } \\
\text { children depend on parents, } \\
\text { and created close bond; if } \\
\text { had known would be } \\
\text { divorced would have } \\
\text { worked part-time to keep } \\
\text { current/visible }\end{array}$ & $\begin{array}{l}\text { Yes: Enjoy working; with } \\
\text { entrepreneurial husband needed job } \\
\text { with reliable benefits; then, } \\
\text { managers could not work part-time } \\
\text { and part-timers did not receive } \\
\text { benefits; would cut back on hours } \\
\text { worked when child was young }\end{array}$ & $\begin{array}{l}\text { No: Change from full-time work } \\
\text { stopped focus, momentum, and drive; } \\
\text { did not appreciate work environs; } \\
\text { should only relocate with good work } \\
\text { situation for self; choice was made in } \\
\text { romantic fantasy that shaped life }\end{array}$ \\
\hline But found & $\begin{array}{l}4 \text { children in } 5 \text { years mean } \\
\text { no travel which limits job } \\
\text { opportunity; had to re-start } \\
\text { career at bottom as single } \\
\text { parent to meet youngest } \\
\text { child's medical need }\end{array}$ & $\begin{array}{l}\text { Rejected jobs requiring much travel } \\
\text { or relocation; supportive spouse is } \\
\text { vital; more options now; women } \\
\text { feel guilty, second guess their } \\
\text { choices, and also worry about ailing } \\
\text { parents }\end{array}$ & $\begin{array}{l}\text { Career did not recover from cross- } \\
\text { country move; novelty of part-time } \\
\text { work to travel with husband wore off; } \\
\text { lacked structure/stimulation; grew } \\
\text { lonely; fired help to be with baby }\end{array}$ \\
\hline
\end{tabular}

\section{Cohort Set 4: Respondents With One IIl Child Or No Children}

These final three women, the oldest of the 12, are different in many ways. But none of the three had longterm goals or plans when making formative work-life choices, and none are certain they would make the same choices again. Things have not turned out as hoped for R10 or R12, while R11 remains unresolved regarding results of the career primary orientation that have led her to career success without marriage or children. R12 is the oldest of the twelve women interviewed, and a long-time divorcee with no children who has not remarried. R10 has only one child, and the child has been seriously ill for many years.

R10 and R12 both relocated at pivotal moments in their own developing careers to follow their husband's jobs. Both say that nothing turned out as they had desired or planned when they made their work-life choices. Graduate work delayed the start of R10's career, which was uprooted by relocation and put on backburner due to her 
child's chronic ailments. She describes having been unprepared for the realities of parenting, and having envisioned combining work and family in ways that were not realistic.

R11 describes being part of the Baby Boom generation whose women felt empowered to be able to earn prestigious academic degrees and pursue competitive careers. She describes female Baby Boomers as being able to make choices that prior generations of women did not have, as not having to graduate from school into marriage and parenthood like many of their mothers had done. Her story closely parallels those profiled in Hewlett's 2002 Harvard Business Review article, "Executive Women and the Myth of Having It All." She depicts ability to be fulfilled professionally as a gift her generation of women was given. Marriage and children were not her focal point; there would be time for that after her career was built. That orientation has taken R11 through a series of high profile public sector management positions, and a mid-career shift to higher education. She and R8 have reached the highest career ranks of the twelve women sampled for this study; they are the only two who worked uninterrupted full-time.

Each of the twelve women interviewed have experienced intensely following their work-life choices, and speak memorably and even hauntingly about them. Their collective imprint is incomplete, though, without R12. Her burgeoning career in arts management was dislocated three times as she moved to follow her husband's increasingly prominent jobs. Married late and after a rapid courtship she describes as idyllic, she sought to continue the social whirlwind in their life together and combine it with political and cultural activism. Nesting, entertaining, traveling, and volunteering became R12's priority as the couple's frequent moves disrupted her established networks and mentors. Home-based consulting replaced her full-time work, which her husband's salary made financially unnecessary. Three moves later, R12 found herself largely alone as her husband's work consumed him. She asked for the divorce that followed. Financially naïve, she settled on terms that neither supported her entrepreneurial ventures nor were sufficient to pay the resulting credit card debts she accrued.

When R12 could no longer pay her rent, she was evicted from the luxury New York City apartment in which she had lived, and at age 55 became homeless. She has spent the eight ensuing years unsuccessfully trying to emerge from homelessness. Ironically, it was two unforeseen events within the past twelve months that have allowed her to move from being classified as homeless to the ranks of the working poor. First, her former husband passed away. As a surviving spouse of their long marriage, R12 now receives her former husband's Social Security benefits. Additionally, low-income housing has become in especially short supply in New York City after providing care for displaced victims of Hurricane Katrina. Consequently, the homeless shelter R9 has been living in has been reclassified as permanent low-income housing.

Although they have taken different paths, both R10 and R12 report that relocation when their husbands' jobs changed was a pivotal moment that spiraled them downward. They join R6 and R9 as the four women interviewed who are certain they should have made different work-life choices. All four of those women point to problematic outcomes resulting from relocation. Like R9, R10 would in hindsight have postponed her move until establishing career opportunities for herself in the new location. Like R6, R10 had planned to work part-time after becoming a parent but was unable to do so. Like R9, R12 speaks romantically of her courtship and marriage, and both describe putting aside fulfilling careers to follow and be with their husbands; marriage, not children, was the initial formative factor they identify. All four of these women express feelings of vanished identity and lost direction stemming from the work-life choices they made, and speak nostalgically and longingly about the careers they had begun that are in their view now behind them.

For her part, R11 does not speak longingly about the children she did not have. Her voice is more quixotic. She senses that other women have experienced dimensions of life that she will not, and has been surprised to find social barriers that being single can create professionally. R12 is the only other childless woman in this simple of 12 . The balance she reports having missed was different. She describes her social and civic activity as having encroached on attention she should have given to her business, her over reliance on her husband's projected income as having overshadowed her need to have a Plan B nest egg, and her creativity and drive as having eclipsed her absence of financial/operational management skill and advanced academic credentials. 
Figure 6: Cohort Set 4

\begin{tabular}{|c|c|c|c|}
\hline Cohort Set 4 & Respondent 10 & Respondent 11 & Respondent 12 \\
\hline Age & 49 & $55-59$ & $60-64$ \\
\hline $\begin{array}{l}\text { Children at } \\
\text { home }\end{array}$ & 1 pre-teen chronic & 0 & 0 \\
\hline Marital status & Married & Single & Divorced $10+$ years \\
\hline $\begin{array}{l}\text { Employment } \\
\text { status }\end{array}$ & Re-starting private practice & Full-time tenured college professor & $\begin{array}{l}\text { Attempting to resume career as } \\
\text { entrepreneur after } 8 \text { homeless } \\
\text { years }\end{array}$ \\
\hline $\begin{array}{l}\text { Academic } \\
\text { degrees }\end{array}$ & $\begin{array}{l}\text { Masters Social Work and Dance } \\
\text { Therapy; BA } \\
\text { English/Renaissance Studies }\end{array}$ & $\begin{array}{l}\text { Masters } \\
\text { Public Administration, } \\
\text { BA Political Science }\end{array}$ & $\begin{array}{l}\text { Arts Administration } \\
\text { Certificate, BA Psychology }\end{array}$ \\
\hline Choice made & $\begin{array}{l}\text { Change careers from journalism } \\
\text { to social work/psychotherapy; } \\
\text { delay career start for graduate } \\
\text { work; quit full-time job to spend } \\
1 \text { year with baby and continue } \\
\text { private work; reject part-time } \\
\text { offer by, relocate for husband's } \\
\text { job }\end{array}$ & $\begin{array}{l}\text { Pursue career as primary goal rather } \\
\text { than marriage/children; move } \\
\text { through series of management } \\
\text { positions in major public sector } \\
\text { organizations; at mid-career, moved } \\
\text { to higher education for security and } \\
\text { stimulation }\end{array}$ & $\begin{array}{l}\text { Uproot management level full- } \\
\text { time career in arts administration } \\
\text { three times to relocate for } \\
\text { husband; start consulting } \\
\text { business and actively engage } \\
\text { civically as volunteer and on } \\
\text { non-profit boards }\end{array}$ \\
\hline $\begin{array}{l}\text { Long-term } \\
\text { goal/plan }\end{array}$ & No & No & No \\
\hline $\begin{array}{l}\text { Would make } \\
\text { same choice }\end{array}$ & $\begin{array}{l}\text { No: Things have not turned out as } \\
\text { hoped/planned; assumed would } \\
\text { resume private practice but } \\
\text { child's serious illness commands } \\
\text { full-time attention; family's } \\
\text { relocation disrupted career; lost } \\
\text { link to prior employer }\end{array}$ & $\begin{array}{l}\text { Yes and no: Would have been } \\
\text { frustrated without professional } \\
\text { fulfillment; felt empowered to be } \\
\text { able to pursue career; lacked female } \\
\text { mentors and understanding of how to } \\
\text { navigate career path; had no Plan B if } \\
\text { goals were unattainable or changed; } \\
\text { felt there would be time later to focus } \\
\text { on family; single peer men were } \\
\text { largely absent }\end{array}$ & $\begin{array}{l}\text { No: Nothing turned out as hoped } \\
\text { or planned; three major } \\
\text { relocations in prime years } \\
\text { disrupted career, divorced; } \\
\text { volunteer activity took focus } \\
\text { from business, entrepreneurial } \\
\text { ventures did not turn adequate } \\
\text { cash flow; maxed credit cards to } \\
\text { fund business; evicted from } \\
\text { luxury apartment when could not } \\
\text { pay rent }\end{array}$ \\
\hline
\end{tabular}

Figure 7: Cohort Set 4 (Continued)

\begin{tabular}{|l|l|l|l|}
\hline Cohort Set 4 & Respondent 10 & Respondent 11 & Respondent 12 \\
\hline But found & $\begin{array}{l}\text { Information vacuum about realities } \\
\text { of life with infants, especially those } \\
\text { with chronic medical needs; would } \\
\text { need half-time child care to work } \\
\text { quarter hours at work; should have } \\
\text { identified child care before giving } \\
\text { birth, and postponed move or } \\
\text { stayed behind with child until re- } \\
\text { establishing self professionally } \\
\text { there }\end{array}$ & $\begin{array}{l}\text { Career goals change with time; } \\
\text { being among first women of high } \\
\text { rank brought obstacles; being single } \\
\text { can create social barriers at work for } \\
\text { women; passing time removes } \\
\text { options; women who made other } \\
\text { choices have had some experience } \\
\text { that will be missed }\end{array}$ & $\begin{array}{l}\text { Should have balanced business } \\
\text { and social/civic activity by } \\
\text { volunteering less; creativity and } \\
\text { drive are not enough to succeed } \\
\text { in business; also need } \\
\text { financial/operational skill, } \\
\text { discipline, mentors, and ability } \\
\text { to handle isolation; important to } \\
\text { build up a financial nest egg } \\
\text { without depending on spouse for } \\
\text { support; value of earning } \\
\text { graduate degree }\end{array}$ \\
\hline
\end{tabular}




\section{Overall}

From these interviews, the unexpected emerges. Anticipating an "aha" moment, the study instead surfaced lingering voices of difficult choices made and disparate actions taken, unanticipated developments and varied consequences experienced, and lives still searching as they are lived. The study looked for a consistent pattern underlying women's formative work-life choices, with special interest as to if the choice to leave traditional employment at life's turning points masked dissatisfaction with glass ceiling or societal value aspects of work that Family Friendly policies will not, in themselves, overcome. But no such simple pattern, and no collective silent scream, took shape.

Half of the 12 women sampled report they would not alter their formative work-life choices. They tend to be the youngest and still actively involved in mothering. On the other hand, the six women who would alter work-life choices they made tend to be older, be furthest removed from active mothering or active working, have interrupted their careers through relocation to follow their husbands' work, and/or have had family lives disrupted by divorce. None of these six women had long-term goals and plans at the time they made their formative work-life balance choice; at most, four of the 12 women sampled had long-term goals and plans in place when making that choice.

Some of these 12 adult women wonder about roads not taken, and some are adrift about getting back on tracks they would like to take. What stress and guilt the 12 express is directed neither at husband nor children. Responsibility for choices made and resulting outcomes is either retained by the woman, or directed at past or potential employers. Serving as a role model for their children was mentioned as a factor, in addition to the impact of role models and networks available to these women.

Balance appears to be important to all, but to have varied meanings. Some of the 12 women sampled sought to balance demanding full-time jobs with enriching family lives. Others sought to balance enervating aspects of athome life with fulfilling professional identity. Still others sought to balance deficits in skill sets, work patterns, credentials, or self-sufficiency.

Something perhaps even more striking emerged. The 12 women sampled differ from each other in many ways. Yet each speaks with intensity, insight, and passion about what is clearly a common journey. Whether or not they have children, husbands, jobs, or careers - whether or not they are satisfied with the work-life choices they have made regarding these - the choices and their consequences are deeply felt.

\section{COMING OR GOING}

The study conducted for this paper set out to query contemporary work-life choices, midst heightening clamor for corporate policies accommodating parental responsibilities. Perhaps more than anything else, the results point to the importance of not oversimplifying operative factors; false dichotomy is likely to breed faulty prescription. Beyond the many objective findings, what emerges is an intimate and frank look at adult women's lives, and the hopes and plans that shape them. Collectively they cover a vast canvass of talents, dreams, emotions, and actions. But the 12 adult women had something else in common. Each has made career and life choices, and is actively experiencing the ripple effects those choices produced.

Some are coming, some are staying, and some are going. Exploring the circumstances within which that choice will be made in the $21^{\text {st }}$ century workplace both clarifies the implications of the responses this study's respondents have provided, and what may impact choices contemporary workers will make.

There are many indicators that a choice to leave one's $21^{\text {st }}$ century job might not be as difficult to make conceptually as it was in the days of presumed lifetime employment, that the psychological contract between company and worker has changed. Erosion of job security coupled with growing free-agency appears to have reduced job loyalty, and heightened the importance to employees of things other than work (Brady, 2004). At many companies, employee morale is at record lows; half of those employed worldwide are disengaged at work (Gandossy and Kao, 2004). 
The portrait of discontent is stark. Less than one-half of U.S. workers are happy with their jobs (Tucker, 2003), and some $95 \%$ of those who leave traditional full-time work would not consider going back to their previous employers (Shiller, 2005). Quitting for women is driven by job dissatisfaction as well as by a pull to motherhood (Belkin, 2003).

A recent Catalyst study explored workplace discontent. It found that less than half of workers in the prime child-bearing years of mid-20 to mid-30 would be happy to spend the rest of their career with their current organization. Far more women $(42 \%)$ than men $(11 \%)$ reported that women have to outperform men to get the same rewards where they work, and far more men (62\%) than women (30\%) reported that women are paid comparable salary to men doing similar work where they work. Some $83 \%$ of working women in this age group and $69 \%$ of peer men report the importance of flexible work arrangements to career advancement and satisfaction (The Next Generation, 2005).

A Catalyst study reported the top reasons those aged mid-20 to mid-30 leave an employer are to increase intellectual stimulation (77\%), advancement opportunity (75\%), and compensation (72\%). Older workers give similar reasons to those reported by younger workers. The top three reasons senior women would leave their current organization are to increase compensation (42\%), develop new skills or competencies (35\%), and pursue greater advancement (33\%). Their male peers give the same three reasons (Catalyst Quick Takes, 2005).

Advanced education does not appear to inoculate against discontent. Some $41.4 \%$ of MBA women and $32.8 \%$ of MBA men are not excited about their work. At the same time, $63.9 \%$ of MBA women and $55.8 \%$ of MBA men do not believe their work contributes value to society (Women MBAs, 2004).

Perhaps as a consequence of such discontent, time spent away from work by those who opt out may result in their seeking work with different employers upon reentry. The majority of women who return to work change both industries and functional roles. While away from work they reflect on where they want their careers to go next. Many decide to follow a new interest; others want a change from industries they now see as inflexible and not conducive to advancement. Several find the industries where they worked have been affected by economic slowdown (McGrath et. al., 2005).

Career stage at reentry may also be an operative but silent factor in choosing new direction at workplace reentry. Many mid-career women have already proven themselves, and are drawn to new sources of satisfaction they are reluctant to speak of. Needs of ailing parents can offer these women an excuse to pull away from work they have outgrown, a chance to look inward, and a new start (Gross, 2005).

Those seeking to create a workplace that retains workers or re-attracts workers at reentry, then, may want to take career goals into account. The majority of highly qualified women identify such goals as ability to associate with people they respect (82\%), freedom to be themselves at work (79\%), chance to be flexible with schedules (64\%), and opportunity to receive recognition at work (51\%). Only $15 \%$ single out attaining a powerful position as important to them. Some $48 \%$ of highly qualified males are ambitious, but only $35 \%$ of their females peers are. Just $31 \%$ of young highly qualified women are extremely or very ambitious (Hewlett and Luce, 2005). That relatively low level of ambition, though, does not translate to disinterest in growth and support. Top reasons workers aged mid-20's to mid30 's give for being attracted to an organization are advancement opportunity (88\%), appropriate position offered (79\%), compensation offered (79\%), organization's reputation (77\%), and benefits (76\%) (The Next Generation, 2005).

Catalyst has identified two categories of factors causing workers to leave their jobs: pull factors and push factors. People may be pulled from their current jobs by offers of much greater compensation or power, drive to fulfill a long-held career ideal, or commitments to family. Alternatively, they may feel pushed from their current jobs by perceived limits to opportunity and career paths, inadequate senior level role models, overload from poor management and bureaucracy, and insufficient concern for their personal lives (Catalyst Quick Takes, 2005). 
Career goals appear to increasingly intertwine with life goals. Work-life balance is the number one factor in job satisfaction for workers aged 35 or under (Dwyer, 2005). Women who work for companies with three or more formal work-life policies are least likely to leave (Hewlett and Luce, 2005).

\section{STEPPING OUT OR STEPPING UP}

The experience and perspective shared by this paper's respondents are consistent with the studies conducted by others. Together, they suggest that the current phenomenon of working women choosing or planning to step out from traditional employment is more than a Mommy Trek. Operative factors appear to be many. Those interviewed for this paper surfaced several recurring themes including unclear paths, relocation uprooting networks and mentors, absence of business or career savvy, lack of fulfillment, aspiration to make meaningful contributions, unsatisfied entrepreneurial or creative drive, financial impact, romanticized notions of work or life, desire to have and be part of family, and needs of significant others. They also surfaced some of their choices' unintended consequences including loneliness, boredom, loss of identity and confidence, stress, guilt, and frustration, as well as career derailment. The further in time they were from the formative work-life choice they had made the more likely they were to report they would, in hindsight, have chosen differently - especially if they lacked long-term goals and plans when making that choice. They hold themselves and/or employers, not their husband or children, responsible for the choice made.

In many ways, women leaving work appear to be seeking to step up rather than to step out. Organizations seeking to operationalize their commitment to, and reap the benefits of, supporting their employees' unaddressed interests may gain by considering the array of reasons associated with stepping out when formulating programs. Catalyst reports that employers can help retain their workers by focusing on the factors over which they have most leverage, which it finds are mostly tend to be the push factors described above (Catalyst Quick Takes, 2005).

Companies who also seek to step up in this way may want to anticipate and try to prevent a ripple effect that some are experiencing: creation of a two-tiered workplace in which some employees feel disfavored. Many workers who do not have children are feeling overlooked and dismissed as their organizations offer policies that accommodate colleagues with children (Johnson, 2006). Such perception can only add to already high levels of worker discontent and disengagement. Some companies are responding to that perception with benefits ranging from on-site dry cleaning to spa treatments to in-house doctors/nurses to personal shoppers that show all types of workers that their time is valued (Johnson, 2006).

Some universities are stepping up, too. Harvard and Dartmouth, for example, are creating intensive executive training programs to help professional women update their skills and reenter the workforce, in response to the corporate sector's need to find increasingly scarce top talent (Rosen, 2006).

Organizations with policies and programs designed to support their employee's need for whole and balanced lives might do well to label them as work-life programs, enhancement programs, or development programs rather than as family-friendly programs. Including substantive career planning, transition, relocation, and reentry training for workers at all levels in such programs is also suggested by this paper's findings. Broadening access to all workers also overcomes the need for workers to reveal personal aspects of their lives at work. Maintaining that zone of privacy not only maintains faith with equal employment opportunity considerations, but also reduces appearance of a two-tiered workplace. Most importantly, diagnosing the work climate and substantively targeting significant push and pull factors detected may optimize outcomes for organizations seeking to step up to erode a tide of workers choosing to step out.

\section{RECOMMENDATIONS FOR FUTURE RESEARCH}

The work-life choices being made in the end are very complex. Examining one set of questions seems to trigger another. Factors associated with attracting, retaining, or disengaging the increasing majority of workers interested in work-life balance have been explored. Much of the literature, though, focuses on the perspectives of adult women who have prioritized career, mothers who have combined work and family responsibilities, or women who have discontinued working. But as seen in a recent study by the Society for Human Resource Management, today's 
working men rank balance (4.43 out of 5.0) at a level similar to working women (4.45 out of 5.0), and are increasingly seeking schedules allowing them that balance (Dwyer, 2005). Further research into male interests, needs, and perspectives regarding work-life balance would seem to be valuable

Ask the Children broadened the field by adding perspectives of working parents and children of working parents (1999). But that study was published seven years ago, in a pre-9/11 economy, and the children sampled were young and still at home. In crafting policies that optimize long term impacts and resonate with emerging workers, it would be useful to know the impact of parents' work-life choices on those their children make when grown. Will their work-life choices be similar to those the parents made?

Other cohort groups whose perspectives would seem to be important are workers who are childless, and workers whose children are grown. Both may encounter responsibilities to care for elder family members, extended family members, or significant others. Overlooking their interests and needs may not only produce inadequate policies, but inject resentment at perceived disparate treatment into already-stressed workplaces. It would seem inadvisable for "the mommy wars" to migrate to the workplace, where it might very well mutate.

The literature might also be enriched by exploring the linkage between current trends in female work-life choices and economic, political, and social conditions. Would a more flourishing economy accompanied by increased opportunity for advancement, compensation, and job security impact women's choices? And to what extent are those choices made to gain social approval or maintain family harmony; are they in any way a sign of learned helplessness, leading to passive and altruistic choices made in reaction to expectation and experience? Moreover, is the work women are choosing to leave intrinsically lacking in significant ways? And has the workplace become so demanding that it no longer even provides the solace from personal stress that The Time Bind described? Such insights might be helpful to organizations wanting to ensure that policies and practices they craft to attract and retain engaged $21^{\text {st }}$ century workers address the operative considerations.

\section{CONVERGENCE}

My mother's mother was a family matriarch who emigrated to the United States from Russia, bore five children three of whom survived beyond childhood, and worked as a seamstress alongside my grandfather tailor to put their children through college and professional school. She lived to 95. Her dying words to me, aged 25, were, "Don't give your ego away."

My father's parents emigrated to the United States from Poland, and worked full days in their bakery. My father insisted his wife would have the right to mother her children full-time. She did so, channeling her abundant energy and drive into significant volunteer roles. One of my younger sister's earliest memories is our mother sobbing, "I am so unhappy." For financial reasons some years later, my parents agreed that my mother could return to work. She rose quickly through the ranks of the real estate company she entered, ran it, bought it, and today - at 84 - is still working and among the highest grossing realtors in her county. My 86 year-old father works beside her.

My brother is a medical doctor. When he encounter the demanding schedule of his residency training he declared, "I need a wife." He married, happily, shortly thereafter.

My sister-in-law was raised in a family where financial circumstances required that both parents work. It was important to her that her children have their mother at home, and she embraced that role she chose. Her youngest child came home from kindergarten one day proudly sharing an assignment she had completed. She had been asked what she wanted to be when she grew up and answered, "When I grow up, I want to work for Daddy just like Mommy does." Shortly thereafter, my sister-in-law enrolled in graduate school.

My sister is a psychologist and holds a Ph.D. She is a single mother raising a son. She frequently declares, "I need a wife." This mantra is heard countless times from working women - from those who are married and those who are single, from those who have children and those who are childless. 
The Mommy Trek turns out to be a convergence. Work and life merge as employer and employee impact each other, family members impact each other, and commitments impact hopes. To explore the Mommy Trek is to encounter the deeply personal. It is sometimes a walk and sometimes a run, propelled by an urge for fulfillment. Organizations seeking to travel in step with their workers on this fundamental journey will do well to be cognizant of its nuances and depth, and to respect its inherent privacy.

\section{REFERENCES}

1. (2006, February 24). Mommy wars. Good Morning America Message Board, ABC News.com, Retrieved from http://forums.go.com/abcnews/GMA.

2. (2005, November 20). Catalyst quick takes. Catalyst Information Center.

3. (2005, November 20). The next generation: Today's professionals, tomorrow leaders. Catalyst.

4. (2004, November 16). Women MBAs from top business schools are more confident about job security than men MBAs are, but women are less excited about the work. Business Wire.

5. (2001, November 1). Looming labor shortages - and reasons why. American Demographics.

6. Belkin, Lisa. (2003, October 26). The opt-out revolution. The New York Times Magazine.

7. Brady, Diane. (2004, November 8). Hopping aboard the daddy track. Business Week, 100-102.

8. Coontz, Stephanie. (2000). The way we never were: American families and the nostalgia trap (reprint). Basic Books (originally issued 1992, Basic Books).

9. Dalke, Anne. (2006, March 9). Summary of Alexis' Bennett '05-'06 brown bag discussion of rethinking science in society. Center for Science in Society, Bryn Mawr College.

10. Dwyer, Kelly. (2005, December 4). Still searching for equilibrium in the work-life balancing act. The New York Times.

11. Federal Glass Ceiling Commission. (1995, November). A solid investment: Making full use of the nation's human capital. U.S. Department of Labor.

12. Federal Glass Ceiling Commission. (1995, March). Good for business: Making full use of the nation's human capital. U.S. Department of Labor.

13. Friedan, Betty \& Quindlen, Anna (introduction). (2001). The feminine mystique (reissue). W.W. Norton \& Company (originally issued 1963, W.W. Norton \& Company).

14. Galinsky, Ellen. (1999). Ask the children: What America's children really think about working parents. William Morrow \& Company.

15. Galinsky, Ellen \& Bond, James, et.al. (2005). Overwork in America: When the way we work becomes too much. The Families and Work Institute.

16. Gandossy, Robert, \& Kao, Tina. (2004). Talent wars: Out of mind, out of practice. HR. Human Resource Planning, 27 (4).

17. Gross, Jane. (November 24, 2005). Forget the career, my parents need me at home. The New York Times.

18. Hewlett, Sylvia. (2002, April). Executive women and the myth of having it all. Harvard Business Review (reprint R0204E).

19. Hewlett, Sylvia \& Luce, Carolyn. (2005, March). Off-ramps and on-ramps: Keeping talented women on the road to Success. Harvard Business Review (reprint R0503B).

20. Hochschild, Arlie \& Machung, Anne. (2003). The second shift (updated edition). Penguin Books (originally issued 1989, Viking Press).

21. Hochschild, Arlie. (2001). The time bind: When work becomes home and home becomes work. Owl Books (originally issued 1997, Metropolitan Books).

22. Johnson, Tory. (2006, February 27). Is it fair to cater solely to employees with kids? ABC News. Retrieved from http://abcnews.go.com/GMA.

23. McCracken, Douglas. (2000, November-December). Winning the talent war for women. Harvard Business Review (reprint R00611).

24. McGrath, Monica, et.al. (2005). Back in the game - returning to business after a hiatus: Experiences and recommendations for women, employers and universities. Wharton Center for Leadership and Change. 
25. Rosen, Ellen. (2006, February 12). Derailed on the mommy track?There's help to get going again. The New York Times.

26. Schwartz, Felice. (1989, January-February). Management women and the new facts of life. Harvard Business Review (reprint 89110).

27. Schwartz, Felice. (1992). Women as a business imperative. Harvard Business Review (reprint 92207).

28. Shiller, Peggy. (2005). Off-ramps and on-ramps: Keeping women on the road to success. Center for WorkLife Policy.

29. Story, Louise. (2005, September 20). Many women at elite colleges set career path to motherhood. The New York Times.

30. Tuckerk, Judith. (2003). The least worst choice: Why mothers 'opt' out of the workforce. The Mothers Movement Online. Retrieved from http://www.mothersmovement.org.

31. Wallis, Claudia. (2004, March 22). The case for staying home. Time. 163 (12), 51-56 and 59.

32. Warner, Karen, et.al. (2005, January-February). Family issues in the workplace: Are students on track? Journal of Education for Business, 80 (3), 145-148.

\section{NOTES}

